\title{
Penetrating neck trauma with a sharp object
}

\author{
Keskin cisimle penetran boyun yaralanmast
}

Tolgahan Çatlı, Harun Gür, Emine Demir, Levent Olgun

Department of Otolaryngology, Bozyaka Training and Research Hospital, İzmir, Turkey

\begin{abstract}
Penetrating injuries of the neck, which consists of major vascular structures, nerves, and many vital organs, may result in life threatening consequences. Although primary causes of trauma include knives and firearms, any penetrating object may lead to injury. This case was found interesting since the foreign object penetrated into deep structures of the neck without causing any severe damage in neurovascular structures, and presented with three-dimensional magnetic resonance angiography images.

Keywords: Magnetic resonance angiography; penetrating neck trauma; vascular injury.
\end{abstract}

It is not uncommon in today's industrialized world to encounter a penetrating injury of the neck, involving approximately $5-10 \%$ of all trauma cases ${ }^{[1]}$ From a piece of metal to a pencil, various types of materials may cause this type of injury. ${ }^{[2,3]}$ Management has changed over the decades in accordance with technological advancements but unfortunately, is still controversial. We present a patient who had a penetrating neck injury by broken glass during a fight. We also aim to discuss different management strategies on this topic while reviewing the literature.

\section{CASE REPORT}

A 19-year-old man was admitted to the emergency room with multiple incisional neck wounds from broken glass during a fight. On examination, his vitals were stable, with no respiratory distress. He was conscious and oriented. Initial hemoglobin level was $13 \mathrm{gm} / \mathrm{dL}$. The wounds were horizontally oriented on the right neck
Bünyesinde ana vasküler yapıları, sinirleri ve birçok vital organı bulunduran boynun penetran yaralanmaları hayatı tehdit edici boyutlara ulaşabilir. Travma nedenleri arasında ilk sırayı bıçak ve ateşli silahlar alırken, delici kesici özelliği olan herhangi bir nesne yaralanmaya yol açabilmektedir. Bu olgu yabancı cismin nörovasküler yapılarda ciddi hasar oluşturmaksızın derin boyun yapılarına penetrasyon göstermesi nedeniyle ilginç bulunmuş, üç boyutlu manyetik rezonans anjiyografi görüntüleri eşliğinde sunulmuştur.

Anahtar sözcükler: Manyetik rezonans anjiyografi; penetran boyun travması; damar yaralanması.

(Figure 1). One of the three lacerations was relatively deep and other two were superficial. There was no active bleeding or hematoma formation. The highest of the wounds was located under the right mastoid apex and it was relatively deep, containing a palpable foreign body (piece of glass). The others were free of foreign body. After the initial assessment magnetic resonance angiography (MRA) of the neck revealed a "triangular shaped foreign body (glass fragment) with a $4 \times 3 \mathrm{~cm}$ dimension" approximately $3 \mathrm{~cm}$ above and lateral to the right carotid bifurcation (Figure 2,3). The patient was operated under general anesthesia to extract the glass fragment followed by primary closure of the wounds (Figure 4). No operative or postoperative complication occurred and the patient was discharged.

\section{DISCUSSION}

The neck is an important anatomical bridge between the body and head, through which various vital structures 


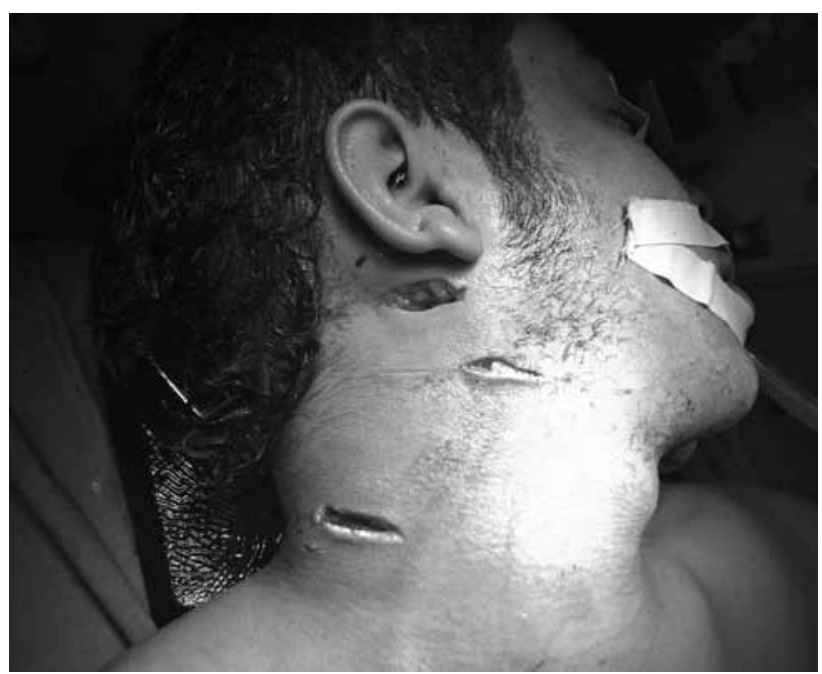

Figure 1. Lateral view of the neck.

such as "main vessels, aerodigestive tract, spinal cord etc." pass. Consequently, any kind of traumatic injury of the neck may result in serious morbidities and death. Mortality from neck trauma has been reported as high as $46 \%$ to $73 \%$ in the literature. ${ }^{[4,5]}$ In medical practice, the neck has been divided into numerous triangles by various muscles. Among these classifications, zonal classification may be the most popular. According to this classification, horizontal lines divide the neck into three zones: Zone I is located between suprasternal notches inferiorly to the cricoid cartilage, zone II is located between cricoid cartilage and angle of mandible

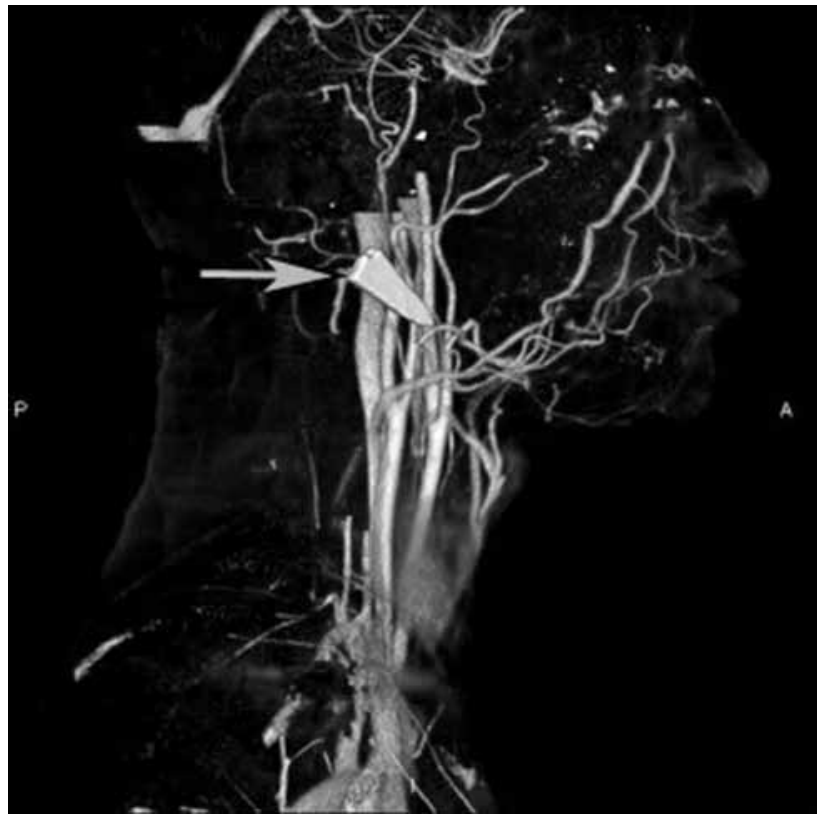

Figure 3. Magnetic resonance angiogram, lateral view, depicting the foreign body lodged close to the right left sided carotid bifurcation (arrow points to the foreign body).

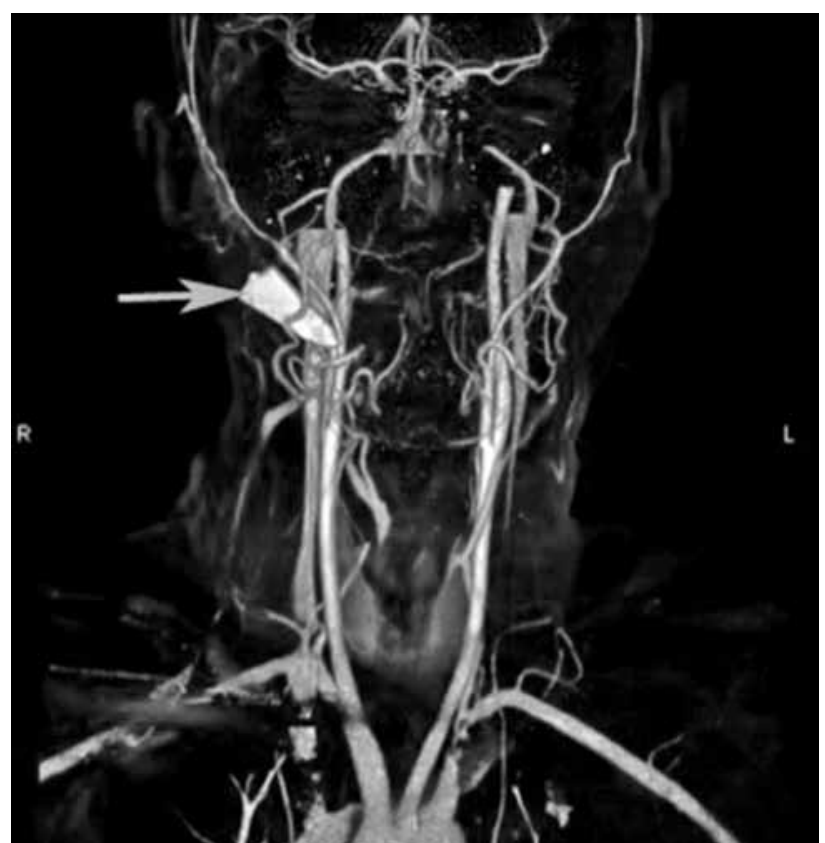

Figure 2. Magnetic resonance angiogram, anteroposterior view depicting the foreign body lodged close to the right left sided carotid bifurcation (arrow points to the foreign body).

and zone III is located between angle of mandible and skull base. These zones have different vulnerabilities to trauma. Although the trauma related with zone I and III is more fatal than zone II, zone II is generally accepted as the most vulnerable zone of the neck to trauma because of its weak bone protection. ${ }^{[1]}$ Additionally, vascular injuries are more frequent for the trauma of zone II than zone I and zone III. Our patient's wounds were located in zone II. For penetrating injuries of zone II it is generally accepted that physical examination and angiography have the same sensitivity for detecting possible vascular injuries. ${ }^{[6]}$ Additionally because of the invasiveness of angiography and risk of allergic reactions, we decided to perform MRA instead to

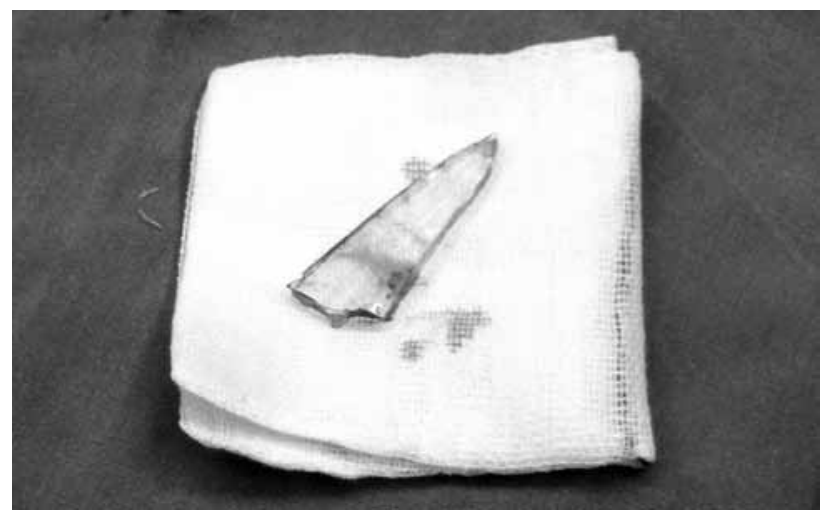

Figure 4. Foreign body postoperative view. 
assess the neck. Magnetic resonance angiography is a noninvasive radiologic assessment that can detect the exact position of the foreign body and the degree of vascular damage. These advantages make MRA superior to angiography in the assessment of penetrating injuries of the neck by a foreign body. Although the first step of management of all trauma cases starts with the assessment of airway, breathing, and circulation, strategies following the initial assessment may vary clinic to clinic for penetrating neck injuries. Mostly it seems to be related to the facilities of the trauma center. It is always the first step to maintain adequate airway and cardiocerebral perfusion in patients. Afterwards, detailed diagnostic and radiologic evaluation may be performed in order to determine the severity of the damage. Urgent exploration is warranted in the presence of active bleeding or progressive hematoma. Routine exploration is advised in places where facilities and a trauma team are not available. However selective conservative management may also be advised in places where required staff and facilities are available. ${ }^{[7]}$ The surgeon has to be aware of the possible tampon effect of the foreign body. In such circumstances, blind extraction of the foreign body may cause acute and massive hemorrhage and mortality. Mortality from penetrating neck injuries is generally due to hemorrhage caused by violated internal jugular vein or carotid artery ${ }^{[8]}$ The foreign body in our case lodged just a few millimeters away from the carotid bifurcation.

In conclusion, penetrating neck trauma requires a careful approach and urgent management due to its high morbidity and mortality rates. To lessen these complications and mortality, the surgeon has to be ready for either rapid surgical exploration or precise radiologic evaluation of the neck. As our experience pointed out, MRA of the neck is a relatively minimally-invasive option for the radiologic evaluation of the deep structures of the neck after penetrating injury.

\section{Declaration of conflicting interests}

The authors declared no conflicts of interest with respect to the authorship and/or publication of this article.

\section{Funding}

The authors received no financial support for the research and/or authorship of this article.

\section{REFERENCES}

1. Ozturk K, Keles B, Cenik Z, Yaman H. Penetrating zone II neck injury by broken windshield. Int Wound J 2006;3:63-6.

2. Rothschild MA, Karger B, Schneider V. Puncture wounds caused by glass mistaken for with stab wounds with a knife. Forensic Sci Int 2001;121:161-5.

3. Pickles JM. Retropharyngeal abscess complicating a neck wound (a case report). J Laryngol Otol 1988;102:552-3.

4. Ramasamy A, Midwinter M, Mahoney P, Clasper J. Learning the lessons from conflict: pre-hospital cervical spine stabilisation following ballistic neck trauma. Injury 2009;40:1342-5.

5. Breeze J, Allanson-Bailey LS, Hunt NC, Delaney RS, Hepper AE, Clasper J. Mortality and morbidity from combat neck injury. J Trauma Acute Care Surg 2012;72:969-74.

6. Jarvik JG, Philips GR 3rd, Schwab CW, Schwartz JS, Grossman RI. Penetrating neck trauma: sensitivity of clinical examination and cost-effectiveness of angiography. AJNR Am J Neuroradiol 1995;16:647-54.

7. Hussain Zaidi SM, Ahmad R. Penetrating neck trauma: a case for conservative approach. Am J Otolaryngol 2011;32:591-6.

8. Fox CJ, Gillespie DL, Weber MA, Cox MW, Hawksworth JS, Cryer CM, et al. Delayed evaluation of combat-related penetrating neck trauma. J Vasc Surg 2006;44:86-93. 